\title{
Book Notice: A New Book of Germanic, Jewish, Romance and Slavic Linguistic Interest
}

Gold, David L. 2009. Studies in Etymology and Etiology (With Emphasis on Germanic, Jewish, Romance, and Slavic Languages). Selected and Edited, with a Foreword, by Félix Rodríguez González and Antonio Lillo Buades. Alicante. Publicaciones de la Universidad de Alicante. 870 pp..

Dictionaries usually accord only brief treatment to etymologies and even etymological dictionaries often do not lavish on them the attention they deserve. To help fill the gap, the author deals in depth with certain words and expressions in various Germanic, Jewish, Romance, and Slavic languages, all of which have hitherto either been misetymologized or not etymologized at all (the three most detailed chapters - 14, 16, and 31 - are respectively 105, 131, and 135 pages long). Sometimes, he succeeds in cracking the nut; sometimes, he can propose only possible solutions; but always he clears away misunderstanding and sets the stage for further serious treatment.

Usually, the author marshals not only linguistic but also historical and cultural information, his approach thus being both linguistic and philological (as William Labov has said, "All linguistics is sociolinguistics"). He deals too with etiology, an often essential but not infrequently neglected component of etymological research. For example, dictionaries in all languages that include an expression translating literally as 'Molotov cocktail' not only misetymologize it but also either fail to etiologize it (why does it commemorate Vyatsheslav Mikhailovitsh Molotov?) or misetiologize it. Chapter 10 (42 pages), based in part on an examination of relevant Finnish military terms and other Finnish sources, presents, for the first time, the right etymology and the right etiology.

This book, which consists of thirty chapters in English and one in romanized Yiddish, (a) raises the level of the discussion in a discipline plagued by unprofessionals; (b) discusses methodology (notably in chapter 11 but also in most others) and thus has the makings of an introduction to the science, art, and craft of etymology; (c) can be used as a reader in courses in diachronic linguistics in general, in etymology in particular, in the history of several families of languages, and in the history of a good number of individual languages; (d) is profitable reading for the educated laity interested in the origin of words and expressions, especially if curious why certain etymological proposals are right or likely and others are wrong or unlikely; and (e), because it contains chapters of varying degrees of difficulty, deals with diverse languages, tries to tackle different kinds of problems, and employs a variety of methods in that endeavor, appeals to a broad variety of readers.

The titles of the chapters are:

1. The Alleged Russian Origin of French bistro bistrot 'wine merchant; public house' Versus Its Probable Ultimate Origin in Vulgar Latin or Gallo-Romance (On the 
Persistence of a Folk Etymology and Folk Etiology Despite the Suggestion of Better Etymologies)

2. The Origin of Chicano Spanish blanquillo 'testicle' (On How Emulated Dyosemy Can Defeat the Purpose of a Euphemism)

3. The British English Origin of Informal Israeli Hebrew braso

4. American English Slang copacetic 'fine, all right' Has No Hebrew, Yiddish, or Other Jewish Connection

5. The American English Slangism fink Probably Has No Jewish Connection

6. Definite and Possible English Reflexes of Spanish garbanzo 'chickpea'

7. Originally American English glitz, glitz up, and glitzy Probably Have No Yiddish Connection

8. Towards a Dossier on the Still Unclear Immediate Etymon(s?) of American English Slang hooker 'whore' (With Remarks on the Origin of American English Barnegat, Dixie, fly vlei vley vlaie vly, Gramercy Park, Hell Gate, jazz, sloughter, and Spuyten Duyvil)

9. American English jitney 'five-cent coin; sum of five cents' Has No Apparent Jewish or Russian Connection and May Come from (Black?) Louisiana French jetnée (On the Increasing Difficulty of Harvesting All the Grain)

10. Etymology and Etiology in the Study of Eponymous Lexemes: The Case of English Molotov cocktail and Finnish Molotovin koktaili

11. Nine Criteria for Assessing the Likelihood of Yiddish Influence on English (With Examples)

12. English paparazzo < Italian paparazzo $=$ Commonization of the Label Name Paparazzo (in Federico Fellini's La Dolce Vita) < ?

13. New York City English parky 'park-keeper' Is Probably a Spontaneous Coinage Rather than a Borrowing from British English

14. When Chauvinism Interferes in Etymological Research: A Few Observations on the Supposed Vulgar Latin Derivation of Rumanian pastramă păstramă, a Noun of Immediate Turkish Origin (With Preliminary Remarks on Related Words in Albanian, Arabic, Armenian, English, French, Greek, Hebrew, Judezmo, Polish, Russian, SerboCroatian, Spanish, Turkish, Ukrainian, and Yiddish)

15. An Immediate or Non-Immediate Jewish Connection for Dutch poeha and Variants (> Afrikaans bohaai > South African English bohaai), French brouhaha (> English brouhaha), French Brou, brou, ha, ha, Brou, ha, ha, High German buhai and Variants, Low German buhê and Variants, or Modern West Frisian bahey and Variants Has Not Been Proven (With Remarks on the Jewish Italian or Liturgical Hebrew Origin of Arezzo Dialectal barruccaba and the Liturgical Hebrew Origin of Italian badanai)

16. Mexican Spanish sarape zarape (Whence American English sarape serape serapi $\sim$ zarape and French sarapé $\sim$ sérapé), a Word Possibly from Tarascan /'ch arakwal, Probably Has No Jewish or Iranian Connection

17. Is Slang American English schnook shnook 'pitifully meek person' from Informal High German Schnuck' 'a kind of small sheep', Northeastern Yiddish shnuk '[elephant's] trunk; snout [of other animals]', or Plattduetsch Schnück 'snail'? 
18. Whence American English scrod and Grimsby English scrob?

19. Does American English shack 'shanty' Come From One or More Uto-Aztecan Languages of the American Plains?

20. The Etymology of English spiel and spieler and Scots English bonspiel

21. English Star Chamber Has No Jewish Connection

22. Who Can Decipher (Yiddish?) *"bashtem" and (Yiddish?) *"ghop bagi"?

23. The (Solely Southeastern?) Yiddish Cloth Name taniklot and the Rare American English Baking Term poolish 'leaven, starter, starter dough'

24. An Instance of Convergence: Frisian witte and Yiddish mideye

25. A Few English Words Misattributed to Yiddish (finagle, finical, finick, toco, trantle, and trantlum); a Yiddish-Origin English Word Misetymologized for at Least Sixty-One Years (bopkes); a Misetymologized Yiddish Pen Name (shmul niger); and a Misetymologized Eastern Yiddish Word (yavne-veyasne!)

26. Etymological and Sociolinguistic Notes of Czech and Jewish or Possible Jewish Interest (On Czech fizl, frajle, hajzl, Hira, ket’as, mecheche, mišuge mišuke, Nabuchodonozor Nabukadnezar, pajzl, pejzy, šmelina, šmelinář, šmok; Yiddish di altnaye shul, peyem peym; Olomouc in Yiddish Lexemes; Franz Kafka's Early Linguistic History; and the Investigation of Yiddish in Bohemia and Moravia)

27. On the Probable Kenaanic Origin of Two Eastern Yiddish Kin Terms, zeyde 'grandfather' and bobe 'grandmother'

28. Zinfandel: An American English Grape and Wine Name of Immediate Hungarian, Moravian Czech, and/or Slovak Origin (On How the Origin of a Significans Need Not Be Parallel to the Origin of the Corresponding Significatum)

29. Nokh a por dugmes fun der yidisher hashpoe af ivrit

30. Some More Israeli Hebrew Items of German Origin

31. Jewish Dickensiana, Part One: Despite Popular Belief, the Name Fagin in Charles Dickens's Oliver Twist Has No Jewish Connection (With Appendixes on Some Laws Concerning Personal Names and on Dickens's Authentic Yiddish Name). 